\title{
IGK Negative
}

National Cancer Institute

\section{Source}

National Cancer Institute. IGK Negative. NCI Thesaurus. Code C162081.

An indication that IGK expression has not been detected in a sample. 